\title{
LEUKAEMIA IN CHILDREN
}

\author{
C.D. KARABUS, M.B. Ch.B., M.Med.(Paed), D.C.H., M.R.C.P., FR.C.P.E.*
}

\section{SUMMARY}

The two major varieties of leukaemia in childhood are acute lymphocytic and acute myeloblastic leukaemia. Subclassification of acute lymphocytic leukaemia has defined groups with a good or poor prognosis and different treatment strategies are employed. Overall, about one third of cases may be cured and results in good prognosis disease are even better. The different varieties of acute myeloid leukaemia all respond less well to treatment, with the major problem being one of maintenance of disease remission. Current treatment of both forms of leukaemia are outlined. Although advances in the management of childhood leukaemia, in particular the lymphocytic variety, have been truly remarkable over the past thirty years, further progress is necessary. Greater refinement of chemotherapy or the use of bone marrow transplantation are the likely avenues for future improvement in prognosis.

The history of leukaemia is a fairly short one. The early nineteenth century French medical literature contains reports of patients with features suggestive of leukaemia. However, the significance of the findings was realized in 1874 by Bennett in Edinburgh and the great Rudolf Virchow in Berlin who almost simultaneously published accounts of patients with large spleens and a peculiar appearance of the blood. In each case there were many more white than red corpuscles. Virchow used the descriptive term of Weisses Blut which, translated into Greek a few years later, became leukaemia. In 1870 Neumann recognized that leukaemia was a disease of the bone marrow. No treatment was available until Farber and colleagues (1948) at the Boston Children's Hospital, achieved the first complete remission of acute leukaemia with the drug aminopterin. This was the start of a chemotherapeutic attack on cancer of all types which has been notably successful in children. Today it is possible that one third of childhood cases of acute lymphocytic leukaemia may be cured of their disease (George et al., 1979).

Leukaemia is a malignancy of the blood-forming organs and affects primarily the bone marrow, liver, spleen and lymph nodes. An uncontrolled increase of white blood cells and their precursors occurs in these and other body tissues. In the blood there are usually obvious changes although the number of leucocytes is often not increased. However, the finding of primitive or blast cells in the blood is suggestive of acute leukaemia. About $20 \%$ of all leukaemias occur in children, with the greatest mortality between 2 and 5 years of age. Leukaemia is the commonest cancer of childhood, in contrast to adults, where solid tumours such as breast and lung cancer occur more frequently. Nevertheless, it is not as common in children as the publicity given to it may suggest. Leukaemia affects about 4 per 100000 of the childhood population per year in the USA. If the incidence here is the same, which is not known, there may be 400 new cases per year in the Republic. The causes of human leukaemia are unknown. A genetic predisposition, radiation or chemicals and viral infections are factors to which most attention has been given. The possibility of a genetic basis for human leukaemia

* Haematology/Oncology Service, Red Cross War Memorial Children's Hospital and Department of Paediatrics, University of Cape Town.

Received 1 May 1981.

\section{OPSOMMING}

Die twee hoofgroepe leukemie in kinders is akute limfositiese en akute mieloblastiese leukemie. Subklassifisering van akute limfositiese leukemie het groepe met 'n goeie of 'I swak prognose onderskei en verskillende behandelinge word gebruik. In die algemeen kan eenderde van gevalle genees word en in goeie prognose groepe is resultate selfs beter. Die verskillende groepe van akute miëloiede leukemie reageer minder goed op behandeling, waar die hoofprobleem die instandhouding van siekteremissie is. Die huidige behandeling van beide vorms van leukemie word omskryf. Hoewel vooruitgang in die hantering van leukemie in kinders, veral in die limfositiese groep, waarlik merkwaardig was gedurendra die afgelope dertig jaar, is verdere vooruitgang nodif Verfyning van chemoterapie of die gebruik van beenmurgoorplanting is die mees waarskynlike rigtings van toekomstige verbetering van prognose.

is of great concern to parents of a child with the disease. Families can be reassured that leukaemia is definitely not inherited through a mutant gene as in haemophilia. There seems, however, to be a slightly increased predisposition to develop acute leukaemia in close relatives of an affected child. Familial cases of the disease are in fact so rare that this possibility need not be taken into account when future pregnancies are considered. A genetic factor in causation of leukaemia seems to be operative in children with Down's syndrome and in the identical twin of a child with leukaemia who has a very high risk of developing the disease shortly after his sibling (Miller 1967). The best established cause in human leukaemia is ionising radiation, such as X-rays or atomic radiation. About 250 cases of leukaemia occurred in the population of Hiroshima and Nagasaki who were exposed to radiation. Patients given radiation therapy also have a higher incidence of leukaemia. However, such exposures occur only in very unusual circumstances and there is no evidence that the tiny dose of radiation to which ordinary people are exposed, including diagnostic X-rays, can cause leukaemia. Viruses have been identified in leukaemia of fowls, mice, rats, cats and other animf but so far no human leukaemia viruses have been demonstrated. How viruses cause leukaemia in animals is not certain. Kaplan (1974) has suggested that they do so in concert with the animal's genetic susceptibility and possibly other external trigger factors. The viruses causing leukaemia, except for those of the cat and some fowl leukaemias, are not infectious in the ordinary sense of being able to spread to other animals. It does not seem that a leukaemia virus can be passed to other species: it is virtually certain that humans do not get leukaemia from infected cats (Hanes et al., 1970).

Leukaemias are classified according to the predominant cell type and the untreated clinical course, acute or chronic. Chronic leukaemia is rare in childhood and the two major paediatric types are thus acute lymphocytic and acute myeloid (or granulocytic) leukaemias. Prior to 1948 the survival of a newly diagnosed patient with acute leukaemia was seldom longer than 4 months.

\section{CLINICAL PRESENTATION OF ACUTE LEUKAEMIA}

There are three major groups of presenting signs and symptons in leukaemia: nonspecific systemic effects, 
features related to invasion of the bone marrow and those due to infiltration of organs other than the bone marrow. Fever is the commonest systemic complaint and may initially be misdiagnosed as an infection, which in fact not infrequently coexists. The bone marrow usually is virtually completely replaced by leukaemia blast cells and this interferes with normal blood formation. Decreased red cell production results in anaemia with its symptoms of pallor, lethargy and breathlessness. Impaired platelet production may lead to purpura, easy bruising and bleeding from the nose and gums. lnfections are frequent owing to lack of production of normal white cells. Invasion of other organs may cause enlargement of liver, spleen or lymphnodes while less often involvement of the brain or testis may be the presenting feature. Bone pain or refusal to walk in young children is a common symptom and occurs in about $25 \%$ of cases. It may be mistaken for rheumatic fever (Schaller, 1972) or even an osteitis.

\section{DIAGNOSIS}

The hallmark of acute leukaemia is the blast cell, an immature or primitive lymphocyte or granulocyte. The diagnosis may be suspected from the blood findings. Anaemia and thrombocytopenia are usual. The white cell count may be very much raised above the normal $4000-1200 \mathrm{U} / \mathrm{mm}^{3}$ and in these cases blast cells are usually obvious. However, in many cases the number of white blood cells is normal or low and the blast cells may not be prominent. Aspiration of cells from the bone marrow is mandatory for confirming the diagnosis. In most cases the marrow is packed with leukaemic blasts while normal marrow cells are decreased or absent.

The second step after establishing the diagnosis is to distinguish between acute lymphocvtic leukaenia (ALL) and acute myeloid leukaemia (AML). This may be possible from the appearance of the blast cells but in some cases special cytochemical stains are necessary to differentiate the two varieties. The distinction is important. Drugs effective in ALL are generally of little use in AML and, of more relevance to the patient, the prognosis for ALL is much better than that of AML.

The final diagnostic step is that of subclassifying the acute leukaemias.

\section{Acute Lymphocytic Leukaemias}

I ALL has been subdivided into three types (L1, L2 and L3) based on the appearance of the blast cells (Bennett et al., 1976). This classification is reproducible and appears to indicate a progressively poorer prognosis. Fortunately, the L1 variety which carries the best prognosis is the typical form of childhood ALL. Immune studies have also designated three classes of ALL: those with T-cell markers, B-cell leukaemia and leukaemia without either marker, the so-called null-cell disease. Null-cell ALL has a much better prognosis than either the $T$ - or $B$-cell varieties. It too is the commonest childhood variety, occurring in about $80 \%$ of cases. The finding that $\mathrm{ALL}$ is a heterogenous disease, has led to the development of different treatment strategies. More intensive therapy is given to the varieties with a worse prognosis. So far, unfortunately, this has not improved the outlook for the child with poor prognosis ALL.

The presenting features which affect the prognosis in ALL are given in Table 1. In addition girls have a better chance of cure than boys and, in the USA as well as in our experience, black children respond less well to treatment than do whites. There does not seem to be any difference in the response of coloured or white children (Karabus and Hartley, 1981).

\section{Acute Myeloid Leukaemia}

There are several different morphological varieties of AML, depending on the predominant cell present. Acute myeloblastic, promyelocytic, myelomonocytic, monocytic and erythroleukaemia are the main types. In general all types respond less well to chemotherapy than the lymphocytic leukaemias. In most published studies only about $15 \%$ of children with acute leukaemia have AML while $80 \%$ have ALL. However the incidence of AML may be higher in black children. In a series of 258 children seen at the Red Cross Children's Hospital, which included 48 black patients, $30 \%$ AML and $64 \%$ ALL. (Karabus and Hartley, 1981).

\section{MANAGEMENT}

One of the most important factors determining whether a child with cancer survives his illness is where he is treated. As childhood cancer is relatively uncommon, patients should be referred immediately to a children's cancer centre. Studies in both the USA (Farber, 1966) and Britain (Witts, 1971) indicate that the ontlook for a child treated at an experienced paediatric centre is much better than that of the patient treated by paediatricians without special expertise in cancer management.

The management of a child with leukaemia involves generai supportive care, treatment of leukaemic effects such as anaemia, bleeding and infection and a specific attack on the primary disease itself.

\section{General Supportive Care}

In order to remove uncertainty and attempt to allay anxiety, the diagnosis should be established promptly and completely. It should then be discussed fully, openly and honestly with both parents. Depending on his age, the patient should also be given some explanation of his condition. The family should be told about the nature of leukaemia, its suspected causes and what the treatment and the course of the illness is likely to be. Potential side-effects of the therapy should be

TABLE I. Prognostic features in acute lymphocytic leukaemia.

Fearure

Age in years

Cell type

Immunologic markers

White cell count

Marrow after 14 days treatment

Immunoglobulins
Good

$3-6$

L1

Null

Less than 10000

Remission

Normal
$B a d$

Under 1 , over 10

L2 or L3

$\mathrm{T}$ or $\mathrm{B}$

More than 50000

No remission

Decreased 
made known prior to their occurrence. The paediatrician should attempt to reduce guilt feelings in the parents and reassure them that the disease is not hereditary, contagious or the result of any lack of parental care. Hospitalisation should be as brief as possible - mainly to establish the diagnosis and during periods of hazardous infection or bleeding. Once in remission the child should be treated as a normal person, attend school and participate in all his former activities. The treating paediatrician should make himself easily accessible to the parents if they wish to discuss a problem or request further information.

\section{Leukaemic Supportive Care}

Children presenting with leukaemia are often anaemic and bleeding. Transfusions of packed red cells or platelets may be necessary. Fever is commonly present and, although it may be due to the disease and not an infection, it is wise to treat all such patients with broad spectrum intravenous antibiotics. Failure to do so may result in death from septicaemia as the child in relapse cannot combat infections effectively. Transfusions of white blood cells may be useful. Initially, metabolic complications may lead to kidney failure and electrolyte disturbances which should be prevented.

\section{Specific Treatment of Leukaemia}

In the 30 years since Farber's report, chemotherapy has revolutionised the treatment of leukaemia. The first and most important goal of treatment is to achieve a complete remission of disease. This occurs when the patient, his blood picture and bone marrow are all normal. It does not, however, mean a cure, the ultimate aim of therapy. The remission must be maintained for a prolonged period in order to cure leukaemia. Once remission is ended by relapse of disease, the possibility of cure by chemotherapy becomes remote and other treatment modalities such as bone marrow transplantation should be considered.

\section{Acute Lymphocytic Leukaemia}

In all types of childhood ALL, remissions can usually be induced easily. The standard regimen of prednisone, vincristine and asparaginase is effective in $95 \%$ of patients and remission is usually achieved within four weeks. These drugs are then discontinued and the second phase of treatment, that of central nervous system (CNS) prophylaxis then begins. CNS prophylaxis, introduced about ten years ago, has been an important step in increasing the cure rate of childhood ALL. Cranial radiotherapy is given with intrathecal injections of methotrexate for a period of two to three weeks. Because of occasional undesirable side-effects, including immune suppression, learning disability and even brain damage, studies have been undertaken in an attempt to reduce to a minimum the amount of CNS treatment needed to prevent local leukaemia. The dose of radiotherapy has been successfully reduced by $25 \%$ (Nesbit et al., 1981) and in children whose initial presenting signs indicate a good prognosis, radiotherapy may be omitted altogether. The final phase of treatment is continuation therapy. In most regimens this includes 6-mercaptopurine and methotrexate, both given by mouth. Patients should be monitored frequently while on treatment and the doses adjusted as indicated by the blood count. Therapy is usually continued for $2 \frac{1}{2}$ to 3 years.

About $50 \%$ of children with ALL can be expected to complete the course of treatment without relapse. In a series of 46 children of all races treated at the Red Cross Children's Hospital between 1970 and 1975, 20 completed therapy (Karabus and Hartley, 1981). Another $20 \%$ can be expected to relapse subsequently, usually within the first year or two after stopping treatment. This figure is not reduced by continuing therapy beyond three years. In boys, relapse not infrequently involves the testes, which should be biopsied before stopping therapy. If leukaemic involvement is found, the testes should be irradiated and chemotherapy contınued tor a turther two years.

After four years off treatment, a child with ALL is probably cured (George et al., 1979).

\section{Bad-prognosis $A L L$}

Children with presenting signs indicating a poor prognosis (Table 1) are generally given a more intensive course of chemotherapy.

Although remissions are usually achieved, early relapse and death is still the usual outcome.

\section{Acule Myeloid Leukaemia}

The phases of treatment are the same as for ALL but the results less successful. Remission induction drugs most often include cytosine arabinoside, daunorubicin and sometimes others such as thioguanine and azacytidine. Only $60-70 \%$ achieve a remission. CNS prophylaxis is similar to that used in ALL but the major problem is the inability of chemotherapy to maintain the remission.

Although the best results (Weinstein et al., 1980) indicate that about $25 \%$ of patients are able to stop treatment, up to now few have survived for longer than five years from diagnosis.

\section{Other Modes of Treatment in Leukaemia}

Immunorherapy. An immune attack on leukaemia with either tuberculosis vaccine as a nonspecific immune stimulant or treated leukaemia cells has not been proved successful.

Bone Marrow Transplantation. Promising results have been reported by Thomas et al., (1979) and this procedure should certainly be considered in children who have relapsed on chemotherapy. Transplantation is much more successful if done during leukaemic remission. Immune incompatability between donor and re cipient is a major barrier to success and the complice tion and mortality rate of the procedure is high.

Progress in the treatment of childhood leukaemia, especially the lymphocytic variety, has been remarkable in the past 30 years. Improvements in the chemotherapy of poor prognosis ALL as well as that of remission maintenance of AML are greatly needed. More effective use of existing drugs as well as the development of new agents may both contribute to greater success. Further development and understanding of marrow transplantation should increase the cure rate even further.

\section{References}

Bennett, J. M., Catovsky, D., Daniel, M-T., Flandrin, G., Galton, D. A. G., Gralnick, H. R. and Sultan, C. (1976). Proposals for the classification of the acute leukaemias: French-American-British (FAB) co-operative group, Br. J. Haematol, 33, 451 - 458.

Farber, S., Diamond, L. K., Mercer, R. D., Sylvester, R. F. and Wolff, J. A. (1948). Temporary remissions in acute leukaemia in children produced by folic acid antagonist 4-aminopteroylglutamic acid. New Engl. J. Med, 283, 787 - 793. 
Farber, S. (1966). Chemotherapy in the treatment of leukaemia and Wilms tumour. J.A.M.A., 198, $826-828$.

George, S. L., Aur, R. J. A., Mauer. A. M. and Simone, J. V. (1979). A reappraisal of the results of stopping therapy in childhood leukaemia. New Engl. J. Med., 300, $269-273$.

Hanes, B., Gardner, M. B., Loosli, C. G., Heidbreder, G., Kogan, B., Marylander, M. and Heubner. R. J. (1970). Pet associations with selected human cancers: A household questionnaire survey. J. Natl. Cancer Inst., 45, $1155-1162$

Kaplan, H. S. (1974). Leukaemia and lymphoma in experimental and domestic animals. Ser. Haematol, 7, $94-103$.

Karabus, C. D. and Hartley, P. S. (1981). Prognosis in acute lymphocytic leukaemia. Submitted to SA Medical Congress, Pretoria.

Miller, R. W. (1967). Persons with exceptionally high risk of leukaemia. Cancer Res., 27, $2420-2423$.
Nesbit, M. E., Sather, H. N., Robison, L. L., Ortega, J., Lutman, P. S., D'Angio, G. J. and Hammond, G. D. (1981). Presymptomatic central nervous system therapy in previously untreated childhood acute lymphoblastic leukaemia: Comparison of $1800 \mathrm{rad}$ and and 2400 rad. Lancet 1, $461-466$.

Schaller, J. (1972). Arthritis as a presenting manifestation of malignancy in children. J. Pediatr., 81, $793-795$.

Thomas, E. D., Sanders, J. E., Flournay, N., Johnson, F. L., Buckner, C. D., Clift, R. A., Fefer, A., Goodell, B. W., Storb, R. and Weidern, P. L. (1979). Marrow transplantation for patients with acute lymphoblastic leukaemia in remission. Blood, 54, 468-476.

Weinstein, H. J., Mayer, R. J., Rosenthal, D. S., Camitta, B. M., Coral, F. S., Nathan, D. G. and Frei, E. (1980). Treatment of acute myelogenous leukaemia in children and adults. New Engl. J. Med., 303, $473-478$.

Witts, L. J. and others (1971). Duration of survival of children with acute leukaemia. Brit. Med. J., 4, 7-9.

\title{
THE CHILD WITH HAEMOPHILIA
}

\author{
C. D. KARABUS, M.B. Ch.B., M.Med. (Paed), D.C.H., M.R.C.P., F.R.C.P.E.*
}

\section{SUMMARY}

Haemophilias are bleeding disorders due to an inherited defect in production of clotting factors. In South Africa 867 haemophiliacs have been registered and 309 of these are boys under 15 years of age. Haemophilia $A$ and $B$ make up about $85-90 \%$ of all cases. They are inherited in a sex-linked manner and thus affect males only. The manifestations of haemophilia are due 10 blecding charricteristically involvine the joints. The disorder varies in severity and in the most severely affected children, repeated haemarthroses may lead to crippling. Early administration of clotting factor, preferably given at the child's home, physiotherapy to prevent muscle wasting and regular assessment by a co-ordinated team of paediatrician, physiotherapist, orthopaedic surgeon and dentist at the hospital are necessary for successful management. These facilities can be rergatised only at a comprehensive haemophilia treatment centre treating a large number of bleeders.

Haemophilia is a term used for a group of life-long bleeding disorders resulting from an inherited defect in the production of one or other of the plasma clotting factors. These proteins, responsible for normal blood coagulation, are designated by the Roman numerals I to XIII. The commonest disorder is haemophilia A or classic haemophilia which was probably recognised as early as the second century. The Babylonian Talmud describes a decision of Rabbi Simon ben Gamaliel to excuse from the rite of circumcision the newborn son of a woman whose sisters' sons bled to death on the basis that 'there are families whose blood is loose, while in others it coagulates'. In 1803 the first modern description was given by $\mathrm{J}$. C. Otto. Haemophilia was called the 'bleeders disease' and later 'the disease of Kings' because of its occur-

* Haematology/Oncology Service, Red Cross War Memorial Children's Hospital and Department of Paediatrics, University of Cape Town.

Received 1 May 1981.

\section{OPSOMMING}

Hemofilie is ' $n$ bloedingsiekte te wyte aan 'n oorgeerfdle defek in die vervaardiging van stollingsfaktore. In Suid-Afrika is 867 hemofilielyers geregistreer en 309 gevalle is seuns onder 15 jaar. Hemofilie $A$ en $B$ beslaan omtrent $85-90 \%$ van alle gevalle. Hulle word oorgeërf in 'n seksgeskakelde manier en tas dus' slegs manlike lyers an. Die kenmerke van hemofilie is te wyte aan bloedings, wat spesifiek gewrigte aantas. Die siekte varieer in die graad van aantasting en in die kinders wat ergste aangetas is, $k$ an herhaalde hemartrose tot erge kreupelheid lei. Vroeë toediening van stollingsfaktor, verkieslik tuis, fisioterapie om spierverval te voorkom en gereëlde evaluering deur' $n$ gekoördineerde span bestaande uit 'n kinderspesialis, fisioterapeut, ortopediese chirurg en tandarts by die hospital is nodig vir suks:svolle hantering. Hierdie fasiliteite kaul slegs bv ' $\mathrm{n}$ omvattende hemofilie behandelingsentrum, wat ' $n$ groot aantal bloeiers behandel, georganiseer word.

rence among descendants of Queen Victoria in the royal families of Britain, Spain and Russia.

Haemophilia $A$ is due to a deficiency in factor VIJI clotting activity while haemophilia B (Christmas Disease) results from defective factor IX production. Both are inherited in a recessive $\mathrm{X}$-linked manner and therefore, with rare exceptions, are manifest only in males. Clinically haemophilia $\mathbf{A}$ and $\mathbf{B}$ are indistinguishable and together they make up about $85-90 \%$ of all cases of haemophilia. Haemophilia A is 5 to 6 times more common than haemophilia B. Of the other haemophilias, Von Willebrand disease is the third most common, comprising about $10 \%$ of patients. All the other clotting factor deficiencies together make up less than $5 \%$ of cases. These disorders are autosomally transmitted and therefore may affect females as well as males.

\section{HAEMOPHILIA A AND B}

Haemophilia is relatively uncommon but not rare. The incidence of haemophilia $\mathrm{A}$ and $\mathrm{B}$ has been found 